\title{
Characterization of submicron aerosols at a rural site in Pearl River Delta of China using an Aerodyne High-Resolution Aerosol Mass Spectrometer
}

\author{
X.-F. Huang ${ }^{1}$, L.-Y. He ${ }^{1}$, M. Hu ${ }^{2}$, M. R. Canagaratna ${ }^{3}$, J. H. Kroll ${ }^{4}$, N. L. Ng ${ }^{3}$, Y.-H. Zhang ${ }^{2}$, Y. Lin ${ }^{1}$, L. Xue ${ }^{1}$, \\ T.-L. Sun ${ }^{1}$, X.-G. Liu ${ }^{2}$, M. Shao ${ }^{2}$, J. T. Jayne ${ }^{3}$, and D. R. Worsnop ${ }^{3}$ \\ ${ }^{1}$ Key Laboratory for Urban Habitat Environmental Science and Technology, School of Environment and Energy, Peking \\ University Shenzhen Graduate School, Shenzhen, China \\ ${ }^{2}$ State Key Joint Laboratory of Environmental Simulation and Pollution Control, College of Environmental Sciences and \\ Engineering, Peking University, Beijing, China \\ ${ }^{3}$ Aerodyne Research, Inc. Billerica, MA, USA \\ ${ }^{4}$ Department of Civil and Environmental Engineering, Massachusetts Institute of Technology, Cambridge, MA, USA
}

Received: 21 October 2010 - Published in Atmos. Chem. Phys. Discuss.: 3 November 2010

Revised: 13 January 2011 - Accepted: 1 February 2011 - Published: 1 March 2011

\begin{abstract}
The Pearl River Delta (PRD) region in South China is one of the most economically developed regions in China, but it is also noted for its severe air pollution due to industrial/metropolitan emissions. In order to continuously improve the understanding and quantification of air pollution in this region, an intensive campaign was executed in PRD during October-November 2008. Here, we report and analyze Aerodyne High-Resolution Aerosol Mass Spectrometer measurements at Kaiping, a rural site downwind of the highly-polluted central PRD area, to characterize the general features of submicron particulate pollution in the regional air. The mean measured $\mathrm{PM}_{1}$ mass concentration was $33.1 \pm 18.1 \mu \mathrm{g} \mathrm{m}^{-3}$ during the campaign and composed of organic matter (33.8\%), sulfate (33.7\%), ammonium (14.0\%), nitrate $(10.7 \%)$, black carbon $(6.7 \%)$, and chloride (1.1\%), which is characterized by high fractions of inorganic ions due to huge emissions of $\mathrm{SO}_{2}$ and $\mathrm{NO}_{\mathrm{x}}$ in PRD. The average size distributions of the species (except $\mathrm{BC}$ ) were all dominated by an accumulation mode peaking at $\sim 450 \mathrm{~nm}$ in vacuum aerodynamic diameter. Calculations based on high-resolution organic mass spectra indicate that $\mathrm{C}, \mathrm{H}, \mathrm{O}$, and $\mathrm{N}$ on average contributed 56.6, 7.0, 35.1, and $1.3 \%$ to the total organic mass, respectively, corresponding to an organic matter mass to organic carbon mass ratio (OM/OC) of $1.77 \pm 0.08$. Based on the high-resolution organic mass spectral dataset observed, Positive Matrix Factorization (PMF)
\end{abstract}

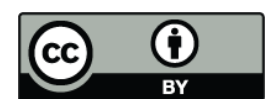

Correspondence to: $\mathrm{L} .-\mathrm{Y} . \mathrm{He}$ (hely@pku.edu.cn) analysis differentiated the organic aerosol into three components, i.e., biomass burning (BBOA) and two oxygenated (LV-OOA and SV-OOA) organic aerosols, which on average accounted for $24.5,39.6$ and $35.8 \%$ of the total organic mass, respectively. The BBOA showed strong features of biomass burning emissions and has been mainly attributed to the open field burning of crop residues after the harvest in PRD rural areas. The LV-OOA and SV-OOA were found to correspond to more aged (and thus less-volatile) and fresher (and semi-volatile) secondary organic aerosol (SOA), respectively. Analysis of meteorological influence supported that regional transport from the central PRD area was the major origin of the $\mathrm{PM}_{1}$ observed at the Kaiping site.

\section{Introduction}

The Pearl River Delta (PRD) region lies in the southeastern coastal part of China and is noted for its flourishing manufacturing and export industries. The urbanization in PRD is now characterized by several big cities like Guangzhou, Shenzhen, and Hong Kong and many medium-small cities linked by dense highways. The rapid economic development and urbanization in PRD in the recent decades comes with the consequence of severe deterioration of its atmospheric environment from urban to regional scale. For example, the annual mean $\mathrm{PM}_{2.5}$ concentrations were reported to range from 29 (for regional background site) to 71 (for urban site) $\mu \mathrm{g} \mathrm{m}^{-3}$ in PRD with organic matter and sulfate as the most abundant constituents (Hagler et al., 2006). The air pollution

Published by Copernicus Publications on behalf of the European Geosciences Union. 
problems in PRD have been a major concern of the national government of China and have raised global scientific interest (Streets et al., 2006; Zhang et al., 2008). As aerosol particles are a complicated mixture of various species, deep understanding of variation of aerosol chemical and physical properties is essential for the purposes of source identification and pollution control. Most previous aerosol studies in PRD were based on filter sampling followed by laboratory analysis, which provided datasets at a coarse time resolution like a day. The coarse time resolution of the aerosol datasets cannot match the actual faster variation of aerosol properties in the real atmosphere, which strongly favors highly timeresolved on-line measurement techniques.

In order to characterize in depth the variation of chemical and physical properties of fine particles in the atmosphere of PRD, an intensive monitoring campaign supported by the project "Synthesized Prevention Techniques for Air Pollution Complex and Integrated Demonstration in Key City-Cluster Region" launched by the Ministry of Science and Technology, China, was organized by Peking University in PRD during October-November, 2008. As part of this campaign, we deployed an Aerodyne high-resolution aerosol mass spectrometer for measurement of submicron aerosol particles downwind of the most polluted central PRD area, in order to better characterize the particulate pollution features in the well mixed and more aged regional air. It was the first application of a high-resolution aerosol mass spectrometer in PRD. Utilizing the advantages of the highresolution aerosol mass spectrometer, highly-time resolved species variations, elemental analysis and source apportionment of organic aerosol (OA) in the atmosphere of PRD were systematically studied in this paper.

\section{Experimental methods}

\subsection{Sampling site description}

The landscape of PRD consists of a flat plain between the Nan Ling Mountains in the North and the South China Sea in the south. Hills surround PRD in the east, west, and north. In the campaign of this study, air monitoring sites were set along the northeast-southwest axis of PRD, as shown in Fig. 1, including two supersites in the rural areas, i.e., Conghua and Kaiping, respectively. In the period of OctoberNovember, under the influence of the East Asian monsoon, the prevailing wind in PRD is northeasterly and thus Conghua is upwind of the central PRD area, while Kaiping is downwind of the central PRD area, receiving pollutants through regional transport. The Kaiping supersite was located at a patriotic educational base $\left(22.32^{\circ} \mathrm{N}, 112.53^{\circ} \mathrm{E}\right)$, about $120 \mathrm{~km}$ away from Guangzhou. This site was surrounded by shrubs and eucalyptus forest and was free of any significant local pollution emissions.

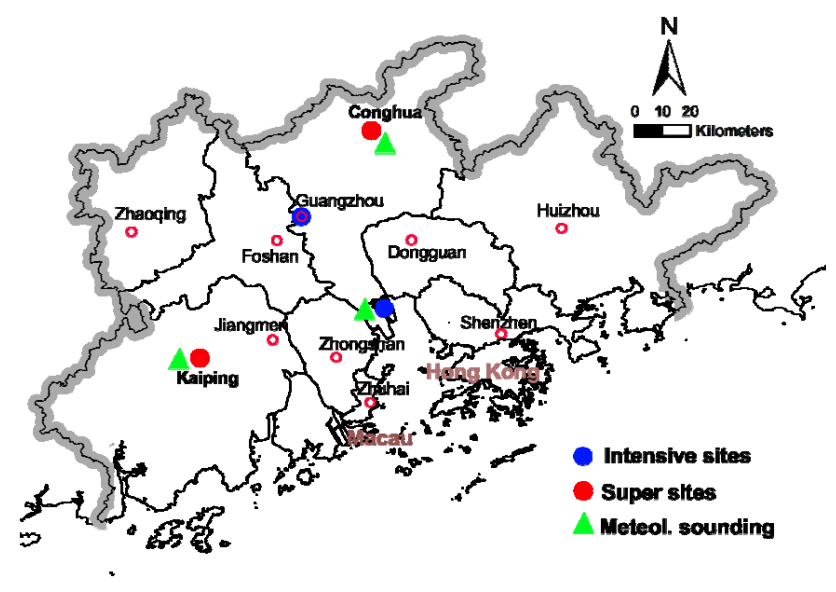

Fig. 1. The location of the Kaiping monitoring site in the PRD region.

\subsection{HR-ToF-AMS operation}

An Aerodyne High-Resolution Time-of-Flight Aerosol Mass Spectrometer (HR-ToF-AMS) was deployed in an air monitoring container settled at the Kaiping supersite from 12 October to 18 November 2008. A detailed instrumental description of HR-ToF-AMS can be found in DeCarlo et al. (2006). A PM 2.5 cyclone inlet was supported on the roof of the container to remove coarse particles and introduce air stream into the container through a copper tube with a flow rate of $101 \mathrm{~min}^{-1}$. The HR-ToF-AMS sampled isokinetically from the center of the copper tube at a flow rate of $80 \mathrm{cc} \mathrm{min}^{-1}$. During the campaign, the HRToF-AMS operated in a cycle of 5 modes every $10 \mathrm{~min}$ utes, including: 2 min V-mode to obtain the mass concentrations of the non-refractory species; 2 min W-mode to obtain high resolution mass spectral data; 4 min separate PToF (particle time-of-flight) mode to determine size distributions of species under the V-mode; and 2 min Soft-EI mode using a lower EI voltage $(\sim 13 \mathrm{eV})$. The PToF mode was not run under the $\mathrm{W}$-mode because of poor signal-to-noise. The Soft-EI mode data are not included in this paper. The HRToF-AMS was calibrated for inlet flow, ionization efficiency (IE), and particle sizing at the beginning, the middle and the end of the campaign following the standard protocols (Jayne et al., 2000; Jimenez et al., 2003; Drewnick et al., 2005). The calibration of IE used size-selected pure ammonium nitrate particles and the particle size calibration was conducted using mono-disperse polystyrene latex spheres (PSL, density $\left.=1.05 \mathrm{~g} \mathrm{~cm}^{-3}\right)($ Duke Scientific, Palo Alto, California, USA) with nominal diameters of $100-700 \mathrm{~nm}$. For a better mass closure measurement of fine particles in the campaign, a Multi-Angle Absorption Photometer (MAAP, Model 5012, Thermo) coupled with a $\mathrm{PM}_{2.5}$ cyclone was used for simultaneous measurement of refractory black carbon (BC), which cannot be detected by HR-ToF-AMS. 


\subsection{HR-ToF-AMS data processing}

Mass concentrations and size distributions of the species measured with the HR-ToF-AMS were calculated using methods outlined in DeCarlo et al. (2006). Standard ToF-AMS data analysis software packages (SQUIRREL version 1.49 and PIKA version 1.08) downloaded from the ToF-AMS-Resources webpage (http://cires.colorado.edu/jimenez-group/ ToFAMSResources/ToFSoftware/index.html) were used to generate unit and high-resolution mass spectra from the $\mathrm{V}$-mode and $\mathrm{W}$-mode data respectively. For mass concentration calculations an empirical particle collection efficiency (CE) factor of 0.5 was used to account for the incomplete detection of species due to particle bouncing at the vaporizer and partial transmission through the aerodynamic lens (Canagaratna et al., 2007). The relative ionization efficiency (RIE) values used in this study were 1.2 for sulfate, 1.1 for nitrate, 1.3 for chloride and 1.4 for organics (Jimenez et al., 2003, Canagaratna et al., 2007). A RIE value of 4.0-4.4 was used for ammonium based on the measurement of pure $\mathrm{NH}_{4} \mathrm{NO}_{3}$ particles.

Positive matrix factorization (PMF) (Paatero and Tapper, 1994) analysis was conducted on the high-resolution (HR) mass spectra $(\mathrm{m} / \mathrm{z} 12-150)$ using the PMF evaluation tool developed by Ulbrich et al. (2009). Compared with unit mass-resolution (UMR) spectra, HR mass spectra can provide better separation of different organic components in PMF analysis (Docherty et al., 2008; Aiken et al., 2009, DeCarlo et al., 2010; Huang et al., 2010). The data and noise matrices input into the PMF analysis were generated with the default fragmentation waves in PIKA version 1.08. The noise values were calculated as the sum of electronic and Poisson ion-counting errors for the relevant high resolution ion fragment (Allan et al., 2003, Ulbrich et al., 2009). The average noise value observed for ions during low signal time periods was used as the minimum error value for the error matrix. The ions of $\mathrm{H}_{2} \mathrm{O}^{+}, \mathrm{HO}^{+}, \mathrm{O}^{+}$, and $\mathrm{CO}^{+}$were not included into $\mathrm{PMF}$ running since they were determined according to their relationship with $\mathrm{CO}_{2}^{+}$and thus including them in the PMF analysis can introduce additional weight to $\mathrm{CO}_{2}^{+}$(Ulbrich et al., 2009). These ions were inserted back into the mass spectra of the resulted PMF components. Weak ions $(0.2<$ signal to noise ratio $<2)$ were downweighted by a factor of 3 while bad ions (signal to noise ratio $<0.2$ ) were removed from the analysis (Paatero and Hopke, 2003; Ulbrich et al., 2009). More technical details of the PMF analysis can be found in another of our recent publication (Huang et al., 2010). Elemental analysis of the organic components identified by PMF was carried out with the methods described previously (Aiken et al., 2007, 2008).

\section{Results and discussion}

\subsection{Variations of $\mathrm{PM}_{1}$ components}

During the entire campaign from 12 October to 18 November 2008 , the average ambient temperature and relative humidity at the Kaiping site were $24 \pm 5^{\circ} \mathrm{C}$ and $69 \pm 15 \%$, respectively, as shown in Fig. 2a. A clear diurnal pattern of wind during the campaign can be observed in Fig. 2b: eastnortheasterly wind usually blew during the day, bringing pollution from the central PRD area to Kaiping, while during the night the wind usually became calm. An exception, however, was that during 8-10 November a cold front passed through PRD, which was characterized by continuous lower temperature and stronger east-northeasterly wind. There were few rainfall events during the campaign that leaded to significant wet removal of air pollutants. These meteorological conditions were very typical of the fall in PRD.

Figure $2 \mathrm{c}-\mathrm{e}$ present the time series of the $\mathrm{PM}_{1}$ mass concentration (the sum of all components measured) and of $\mathrm{PM}_{1}$ components during the campaign. The corresponding statistical values of the concentrations are summarized in Table S-1. During the entire campaign, the $\mathrm{PM}_{1}$ mass concentration was observed to be in a range of $2.4-150 \mu \mathrm{g} \mathrm{m}^{-3}$, with a mean value of $33.1 \mu \mathrm{g} \mathrm{m}^{-3}$. The $\mathrm{PM}_{1}$ variation traced closely $\left(R^{2}=0.86\right)$ the particle volume variation measured with a collocated Scanning Mobility Particle Sizer (SMPS, TSI Inc.) and calculated based on the size distribution between 15 and $600 \mathrm{~nm}$ in mobility diameter by assuming spherical particles. The mass concentrations of $\mathrm{PM}_{1}$ components also varied widely. On average, organics and sulfate had equal concentrations of $11.2 \mu \mathrm{g} \mathrm{m}^{-3}$ and together accounted for $67.5 \%$ of the $\mathrm{PM}_{1}$ mass (in Fig. 2f). Ammonium, nitrate, BC, and chloride accounted for the rest 14.0, 10.7, 6.7, and $1.1 \%$ of the $\mathrm{PM}_{1}$ mass, respectively. It should be noted in this paper that the $\mathrm{BC}$ mass fraction in $\mathrm{PM}_{1}$ is likely overestimated because $\mathrm{BC}$ was measured for $\mathrm{PM}_{2.5}$ by MAAP in the campaign. During the cold front event (November 8-10), the concentrations of all $\mathrm{PM}_{1}$ species showed continuous lower concentrations as a result of higher wind speeds. After this cold front event, the meteorological conditions became back to normal and the $\mathrm{PM}_{1}$ species concentrations became back to higher levels. In addition, it is clearly seen that organics reached and maintained at abnormally high concentration levels (even $>50 \mu \mathrm{g} / \mathrm{m}^{3}$ ) after 12 November. The comparison of average $\mathrm{PM}_{1}$ compositions before and after 12 November is shown in Fig. $2 \mathrm{~g}$, in which it is clearly seen that organics increased by a factor of 2.3 times in ambient concentration during the biomass burning period. A primary explanation for this high OA episode is that rice straw burning became prevalent in PRD after the rice harvest starting in mid November. More detailed analysis of contribution of biomass burning aerosol to OA is performed in Sect. 3.4.

Despite being a rural site, the average non-refractory $\mathrm{PM}_{1}$ (NR-PM $\left.\mathrm{N}_{1}\right)$ mass concentration $\left(29.5 \mu \mathrm{g} \mathrm{m}^{-3}\right.$, without BC) at 


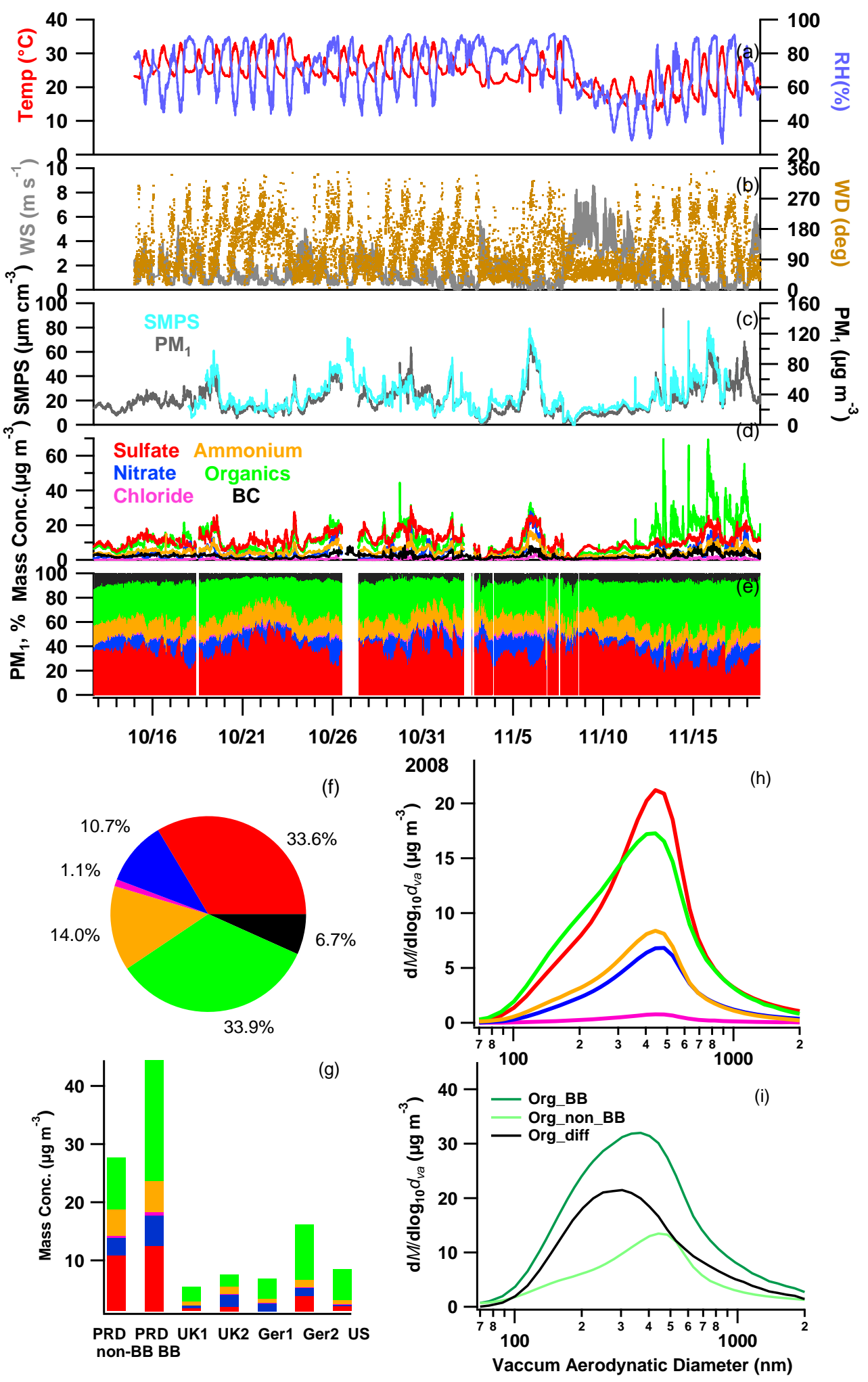

Fig. 2. The time series of (a) ambient temperature and relative humidity; (b) wind direction and wind speed; (c) $\mathrm{PM}_{1}$ mass concentration by AMS species+BC and SMPS volume; (d) $\mathrm{PM}_{1}$ species concentrations; (e) $\mathrm{PM}_{1}$ percent composition; the average (f) $\mathrm{PM}_{1}$ chemical composition; (g) comparison of average species concentrations with other urban downwind sites; (h) mean species size distributions; and (i) mean OA size distributions during biomass burning period (after 12 November) and non-biomass burning period (before 12 November). 

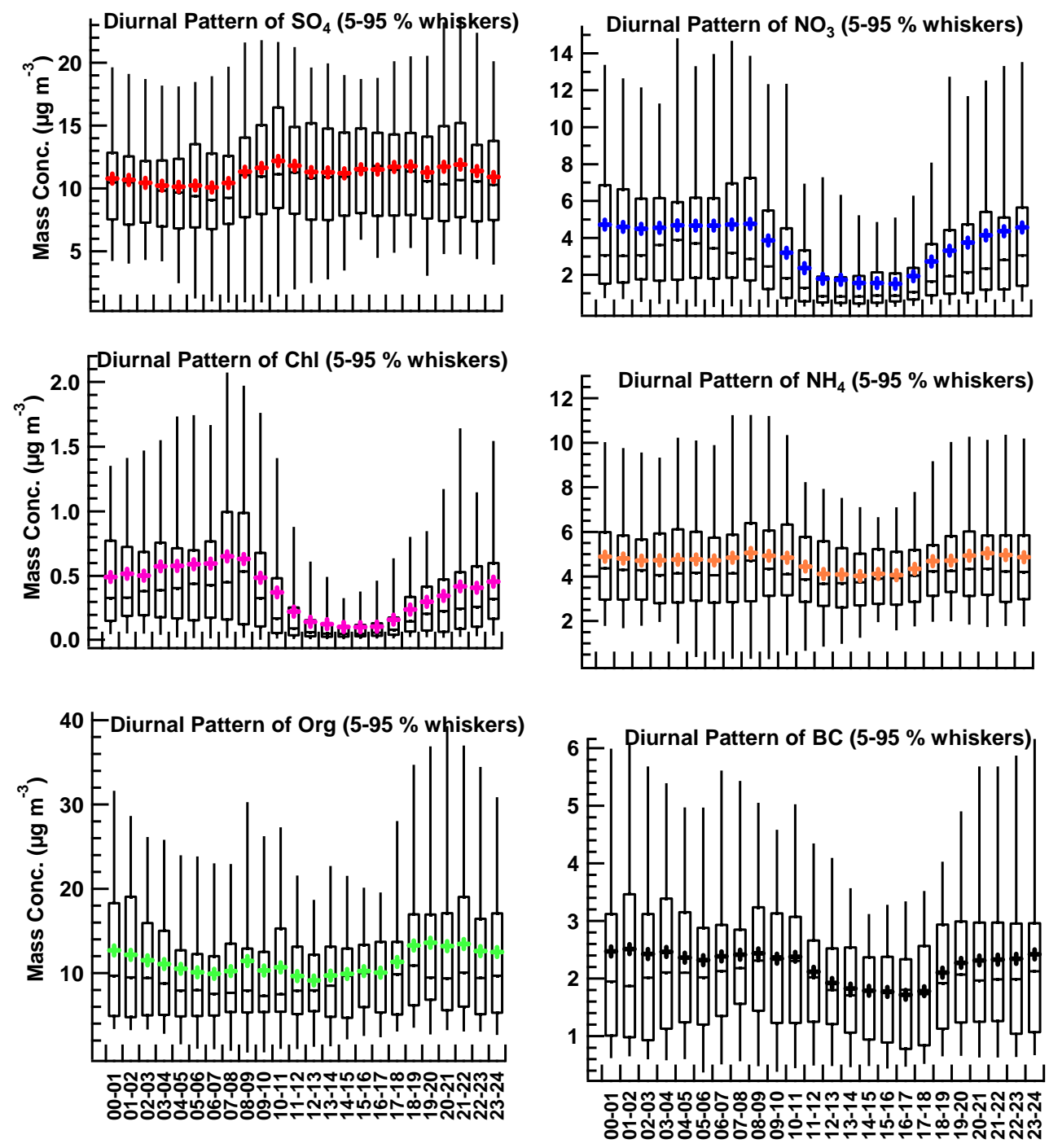

Fig. 3. Diurnal variation box plots of $\mathrm{PM}_{1}$ species. The upper and lower boundaries of boxes indicate the 75 th and 25 th percentiles; the line within the box marks the median; the whiskers above and below boxes indicate the 90th and 10th percentiles; and cross symbols represent the means.

Kaiping during normal days (i.e., before 12 November) is much higher than those observed in the atmospheres in developed countries (below $20 \mu \mathrm{g} \mathrm{m}^{-3}$ ), including at five similar urban downwind sites in UK, US, and Germany (mostly below $10 \mu \mathrm{g} \mathrm{m}^{-3}$ ) (Zhang et al., 2007), as shown in Fig. 2g. In terms of NR-PM 1 components, Kaiping had a far higher concentration level for sulfate due to coal burning, which is still the primary energy source in China. On the other hand, the average NR-PM $M_{1}$ mass concentration at Kaiping is less than half of that in urban Beijing in summer $\left(61 \mu \mathrm{g} \mathrm{m}^{-3}\right)$ (Huang et al., 2010).

Figure $2 \mathrm{~h}$ presents the average species size distributions determined by the HR-ToF-AMS during the campaign. All the species generally showed a similar accumulation mode peaking at a large size of $\sim 450 \mathrm{~nm}$, which is indicative of aged regional aerosol (Allan et al., 2003; Alfarra et al., 2004; Zhang et al., 2005b). Their similar size distribution patterns suggest that most of them were likely internally mixed through gas-to-particle condensation processes during aging of the air mass, which is consistent with the fact that Kaiping was a downwind rural monitoring site. Organics showed some additional mass distribution at smaller sizes of 100$300 \mathrm{~nm}$, suggesting significant input of fresh primary organic aerosols. In the case of this campaign, biomass burning aerosol is implied to be a major contributor to the organic mass at smaller sizes as analyzed in Sect. 3.4. To support this hypothesis, the mean OA size distributions during biomass burning period (after 12 November) and non-biomass burning period (before 12 November) are compared in Fig. $2 \mathrm{i}$. It is clearly seen that the peak of the OA size distribution 
moved from $450 \mathrm{~nm}$ to $350 \mathrm{~nm}$ for the biomass burning period. The difference between them yielded an OA size distribution peaking at $\sim 300 \mathrm{~nm}$, as shown in Fig. 2i, more clearly indicating the contribution from fresh emissions.

\subsection{Diurnal patterns of $\mathrm{PM}_{1}$ components}

Figure 3 presents the diurnal variation patterns of different $\mathrm{PM}_{1}$ species in the form of box plot. In terms of the average cases, the $\mathrm{PM}_{1}$ species roughly exhibited two types of patterns: sulfate, ammonium and organics showed relatively stable concentrations during the whole day; while nitrate, chloride and black carbon showed significantly lower concentrations in the daytime. The higher planetary boundary layer (PBL) and wind speeds in the daytime should be crucial factors leading to effective dilution of air pollutants, and the semi-volatility of nitrate and chloride would further lower their daytime concentrations due to evaporation at higher temperatures (Zhang et al., 2005a; Salcedo et al., 2006; Hennigan et al., 2008; Zheng et al., 2008). The lowest concentrations of nitrate in the afternoon also suggest that the amount of its photochemical production could not overwhelm the simultaneous evaporation and dilution effects. For less-volatile secondary sulfate, its daytime photochemical production might compensate the daytime dilution effect and made its concentration level relatively stable during the whole day. The diurnal variation of ammonium is a combined result of particulate $\left(\mathrm{NH}_{4}\right)_{2} \mathrm{SO}_{4}$ and $\mathrm{NH}_{4} \mathrm{NO}_{3}$. As aerosol organic matter has both large primary and secondary sources and also large amounts of semi-volatile compounds, the observed diurnal variation of organics was a complex outcome of those of different types of organics, which will be provided and discussed in the next section. It is interesting to note that in the $\mathrm{BC}$ diurnal pattern there was an absence of a morning peak. The morning BC peak due to rush-hour traffic and low boundary layer was observed in many previous urban studies (Lin et al., 2009; Han et al., 2009; Aiken et al., 2009). The missing morning BC peak in this campaign, however, is well consistent with the fact that Kaiping is free of significant local traffic emissions.

\subsection{Elemental composition of organic aerosol}

The high-resolution organic mass spectral dataset obtained are used to calculate the elemental composition and OM/OC (the ratio of organic mass/organic carbon mass) of OA following the methods described previously (Aiken et al., 2007, 2008). Figure $4 a$ and $b$ show the variations of the atomic ratios of $\mathrm{H} / \mathrm{C}, \mathrm{N} / \mathrm{C}$ and $\mathrm{O} / \mathrm{C}$ and the mass ratio of $\mathrm{OM} / \mathrm{OC}$ of $\mathrm{OA}$ during this campaign. On average, $\mathrm{C}, \mathrm{H}, \mathrm{O}$, and $\mathrm{N}$ contributed 56.6, 7.0, 35.1, and $1.3 \%$ to the total organic mass, respectively, as shown in Fig. 4c. The $\mathrm{H} / \mathrm{C}$ ratio varies in a range of 1.26-1.69, with a mean value of $1.48 \pm 0.08$, while the $\mathrm{O} / \mathrm{C}$ ratio varies in a range of $0.19-0.78$, with a mean value of $0.47 \pm 0.07$. The $\mathrm{O} / \mathrm{C}$ ratio is regarded as a good reference for oxidation state and photochemical age of organic aerosols (Jimenez et al., 2009; Ng et al., 2010), and thus the variation of $\mathrm{O} / \mathrm{C}$ in this campaign roughly reflects the variation of the aging level of OA at Kaiping. The N/C ratio ranges between 0.008 and 0.036 , with a mean value of $0.02 \pm 0.01$. A notable feature for the N/C variation is its significant elevation during the biomass burning period. The average N/C ratios before and after 12 November are 0.018 and 0.029 , respectively, clearly indicating significant input of high $\mathrm{N}$-containing OA during the biomass burning period. As shown in Fig. S1, the relative intensity of N-containing organic fragments significantly increased during the biomass burning period. However, the direct HR-ToF-AMS measurement of burning plumes of rice straw and five other biomass materials in laboratory by our group did not find N/C ratios of above 0.02 (He et al., 2010). Thus, the high N/C ratios observed near the end of the campaign are inferred to be possibly due to secondary reactions of $\mathrm{NH}_{3}$ and $\mathrm{NO}_{\mathrm{x}}$ with organics in biomass burning plumes and/or simultaneous burning of high N-containing soil materials in the open field. Another possibility is that, biomass burning in PRD may also include other high $\mathrm{N}$-containing biomass materials that were not tested by He et al. (2010), since Laskin et al. (2009) have found high abundance of N-heterocyclic alkaloids in biomass burning aerosols in test burns of ponderosa pine in the US. The OM/OC ratio highly correlates with the O/C ratio $\left(R^{2}=0.98\right)$, having a mean value of $1.77 \pm 0.08$. The $\mathrm{OM} / \mathrm{OC}$ ratio has been extensively used to convert organic carbon mass to organic matter mass in filter-based aerosol chemistry studies, and 1.8 should be a reasonable approximate OM/OC ratio for the Kaiping rural site based on the HR-ToF-AMS elemental analysis.

Figure $4 \mathrm{~d}$ shows a Van Krevelen diagram (H/C versus O/C of $\mathrm{OA}$ ) and an apparent anti-correlation with a slope of -0.76 was observed. The highlighted data points for the biomass burning period in Fig. 4d were mostly distributed in the upper left area, suggesting that the primary biomass burning orgnic aerosols usually had relatively lower $\mathrm{O} / \mathrm{C}$ ratios but higher $\mathrm{H} / \mathrm{C}$ ratios. This is consistent with the elemental composition of the BBOA component extracted from PMF analysis of $\mathrm{OA}$ in the next section. The slope is a little shallower than those (about -1.0) observed in Riverside, the Central Amazon Basin, and Mexico City (Heald et al., 2010). As suggested by Heald et al. (2010), the shallower slope of OA in the Van Krevelen diagram can reflect different aging mechanisms (such as greater tendency of alcohol addition) and/or relative mixes of fresh and aged air masses in the PRD environment.

Figure $4 \mathrm{e}$ and $\mathrm{f}$ present the average diurnal variations of $\mathrm{H} / \mathrm{C}, \mathrm{N} / \mathrm{C}, \mathrm{O} / \mathrm{C}$ and OM/OC. Since the ratios are influenced by relative organic constitutions rather than absolute organic concentrations, their diurnal patterns should be mostly attributed to the diurnal changing of relative importance of different sources. Both the $\mathrm{O} / \mathrm{C}$ and $\mathrm{OM} / \mathrm{OC}$ ratios start to increase at 9 a.m. in the morning, and reach a peak at 3 p.m. 


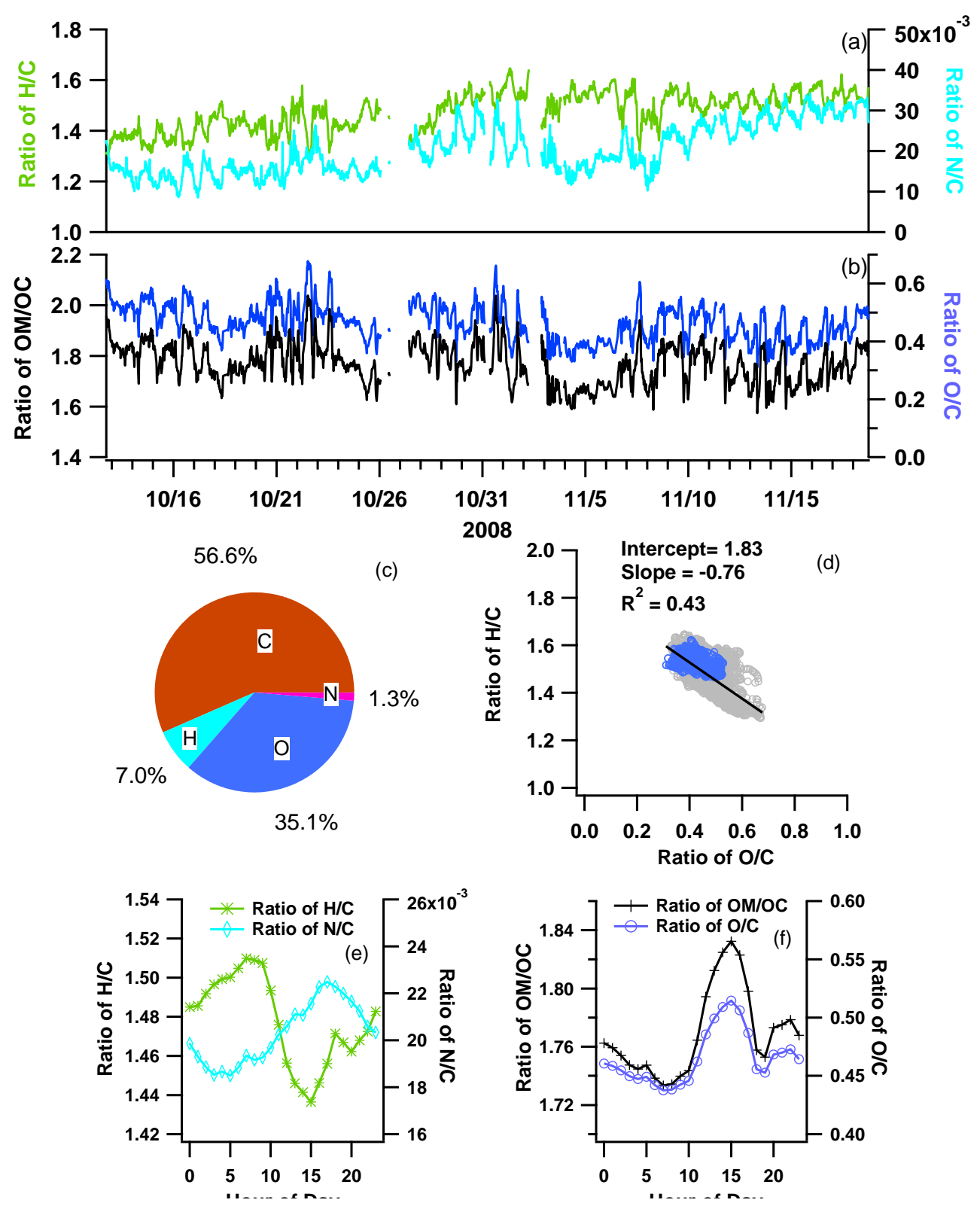

Fig. 4. The time series of (a) $\mathrm{H} / \mathrm{C}$ and N/C ratios; and (b) $\mathrm{O} / \mathrm{C}$ and $\mathrm{OM} / \mathrm{OC}$ ratios; (c) the average mass-based organic elemental composition; (d) the Van Krevelen diagram (with data points during biomass burning period highlighted with blue); the average diurnal variations of (e) $\mathrm{H} / \mathrm{C}$ and N/C ratios and (f) $\mathrm{O} / \mathrm{C}$ and $\mathrm{OM} / \mathrm{OC}$ ratios.

in the afternoon when photochemistry is the most active to produce secondary organic aerosol (SOA) with high O/C ratios. The $\mathrm{H} / \mathrm{C}$ ratio shows a reverse diurnal pattern to those of $\mathrm{O} / \mathrm{C}$ and $\mathrm{OM} / \mathrm{OC}$ as expected. The diurnal pattern of N/C starts to increase at 6 p.m. in the early morning and reaches a peak at 5 p.m. in the late afternoon, which is generally consistent with the daily activities time of local farmers. This may imply that the accumulation of biomass burning-related aerosols in the atmosphere due to daytime burning events could be responsible for the continuous daytime N/C ratio increase.

\subsection{PMF analysis of organic matter composition}

The PMF analysis based on the high-resolution mass spectrum dataset observed in the campaign was performed for 1 to 8 factors, and the results and diagnostics are summarized in Table S2. It can be seen in the table that, PMF solutions with factor numbers greater than 3 resulted in splitting behavior of the existing factors, but provided no new distinct factors. Based on all the qualified tests in Table S2, the three factor, FPEAK $=0$, seed $=0$ solution was chosen as the optimal solution for this analysis. The three organic 


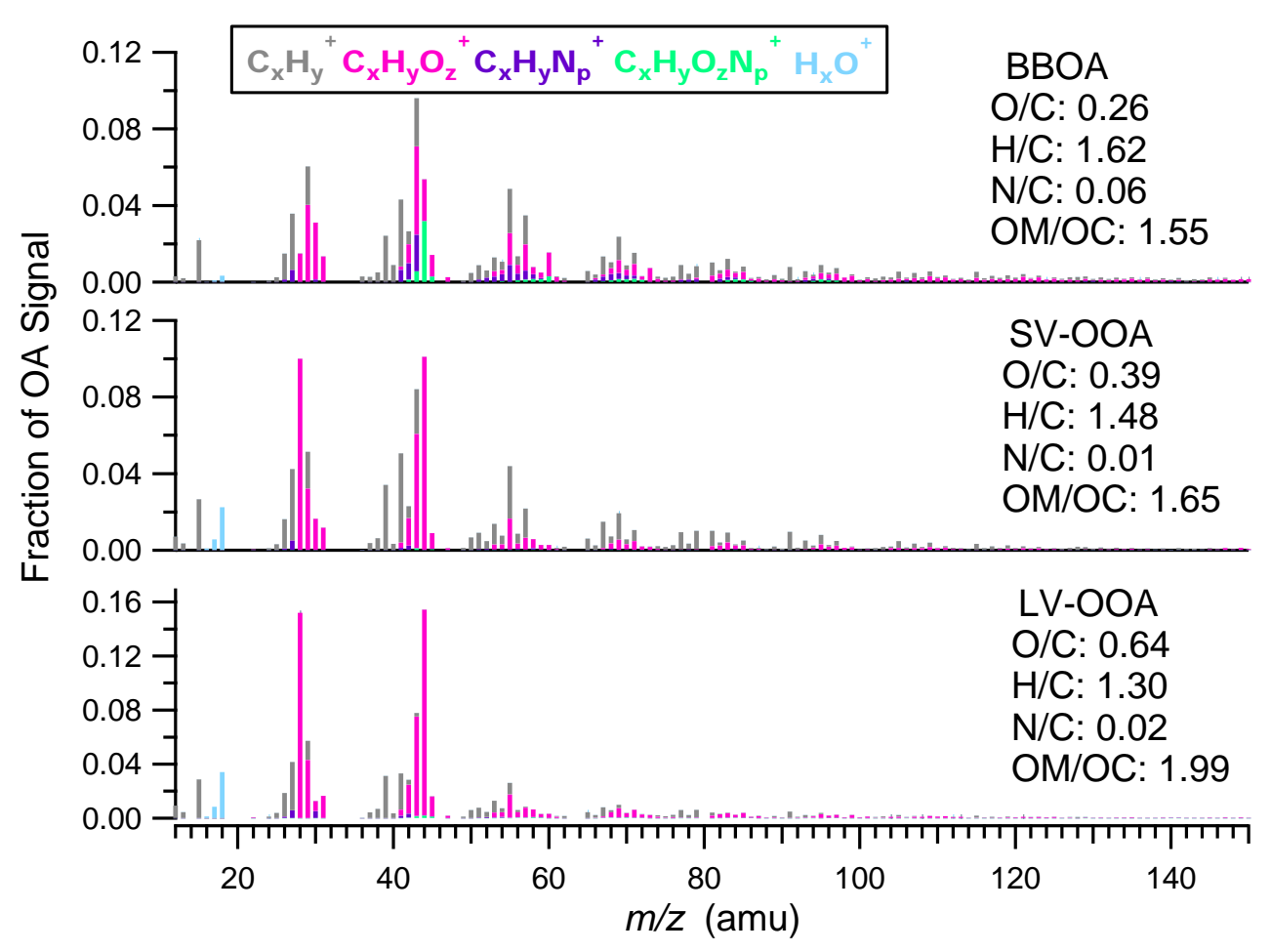

Fig. 5. The MS profiles of the three OA components identified by PMF in this study.

components identified in this campaign include a biomass burning (BBOA) and two oxygenated (SV-OOA and LVOOA) organic aerosol components. Figure 5 shows the MS profiles of the three components and Fig. $6 \mathrm{a}-\mathrm{c}$ present their time series during the campaign. The BBOA, LV-OOA and SV-OOA on average accounted for $24.5,39.6$ and $35.8 \%$ of the total organic mass, respectively, as shown in Fig. 6d. The representativeness of the different components identified will be examined for their MS signatures, correlation with tracers, and other characteristics in the following (Zhang et al., 2005b; Ulbrich et al., 2009).

The BBOA MS has an $\mathrm{O} / \mathrm{C}$ ratio of 0.27 and is distinguished by a prominent contribution of $\mathrm{m} / \mathrm{z} 60$, which is a good tracer ion for biomass burning-emitted aerosols (Alfarra et al., 2007; Aiken et al., 2009). The O/C ratio of the BBOA is similar to those $(0.18-0.26)$ measured for laboratory-produced different primary biomass burning organic aerosols by our group, and the HR-MS of BBOA also showed high correlations with those of the primary OAs $\left(R^{2}=0.67-0.75\right)$ (He et al., 2010). The O/C ratio of the BBOA is also similar to that (0.30) of the BBOA identified in a similar PMF study of the AMS dataset measured in Mexico City (Aiken et al., 2009). In the PMF-resolved time series of BBOA, as shown in Fig. 6a, the large elevation of the BBOA concentration after 12 November (ave. $9.12 \mu \mathrm{g} \mathrm{m}^{-3}$ compared to ave. $1.36 \mu \mathrm{g} \mathrm{m}^{-3}$ before 12 November) is consistent with the fact that biomass burning smoke could be easily smelled at the sampling site during that time. The identification of BBOA in this campaign was an expected result because there are extensive farmlands around the Kaiping site and the farmers in PRD have the habit to burn off rice straw after the rice harvest around mid November. The time series of BBOA is compared to that of the collocated measurement of acetonitrile (in Fig. 6a), a well-known gaseous tracer for biomass burning emissions (de Gouw et al., 2003), using a Proton Transfer Reaction Mass Spectrometry (PTRMS) (Yuan et al., 2010). The correlation between BBOA and acetonitrile $\left(R^{2}=0.60\right)$ is consistent with the interpretation that this component has a biomass burning source. Correlation between BC and BBOA $\left(R^{2}=0.49\right)$ and between $\mathrm{BC}$ and acetonitrile $\left(R^{2}=0.46\right)$ further indicate that biomass burning was an important source of BC at Kaiping.

The MS of the two OOA components had O/C ratios of 0.64 and 0.39 , respectively, and were both characterized by prominent $\mathrm{C}_{\mathrm{x}} \mathrm{H}_{\mathrm{y}} \mathrm{O}_{\mathrm{z}}$ fragments, especially $\mathrm{CO}_{2}^{+}(\mathrm{m} / \mathrm{z} 44)$, suggesting large presence of oxidized organic compounds. OOAs have been extensively identified in previous factor analyses of AMS ambient aerosol datasets and shown to be a good surrogate of SOA (Zhang et al., 2005b, 2007; Jimenez et al., 2009; $\mathrm{Ng}$ et al., 2010). Two types of OOAs with different $\mathrm{O} / \mathrm{C}$ ratios have been observed in many places from urban, suburban, to rural ambient: the OOA with higher $\mathrm{O} / \mathrm{C}$, which is more oxidized and aged, is referred to as lowvolatility OOA (LV-OOA); while the OOA with lower O/C, which is less oxidized and fresher, is referred to as semivolatile OOA (SV-OOA) (Jimenez et al., 2009; Ng et al., 

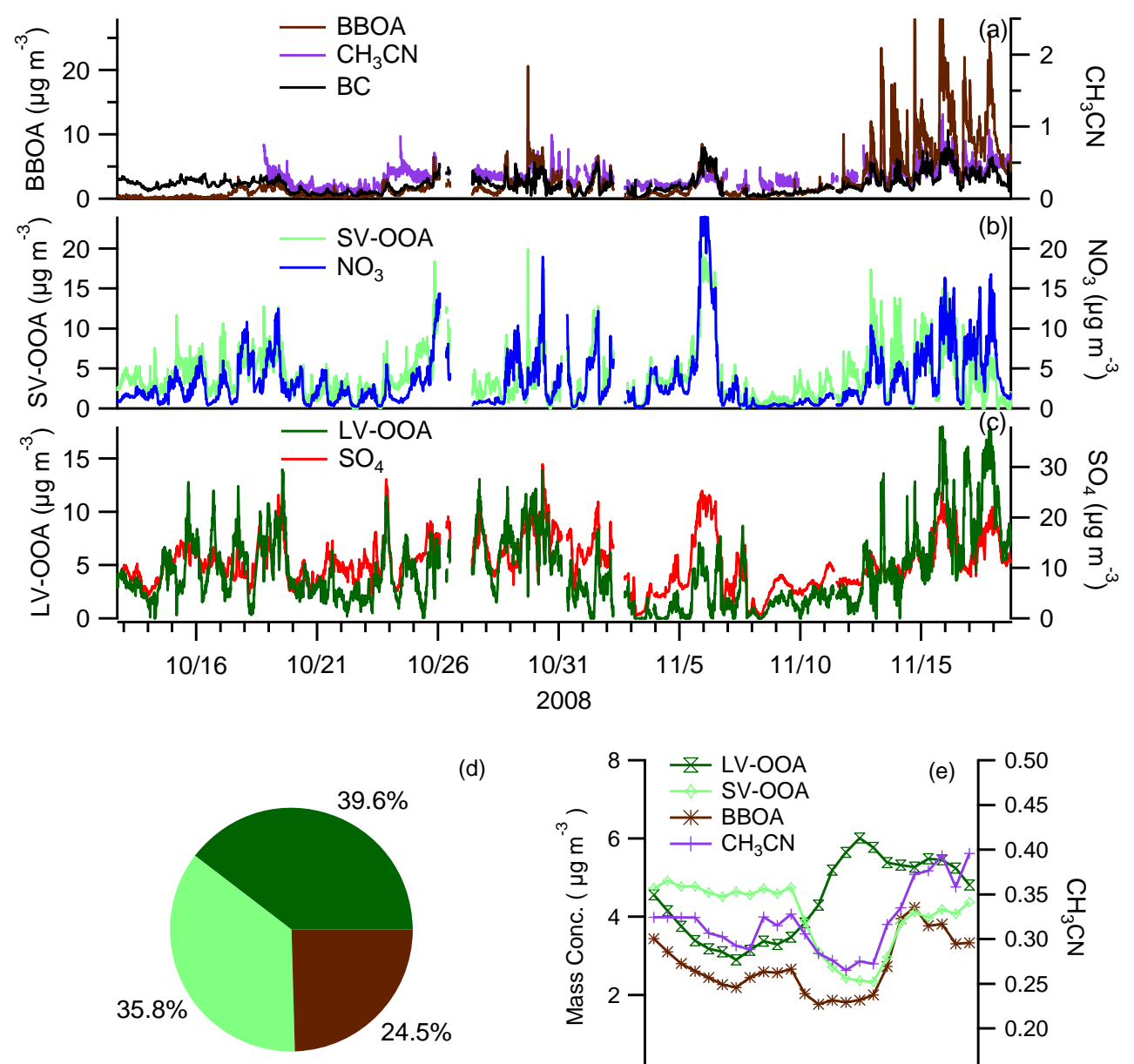

(d)

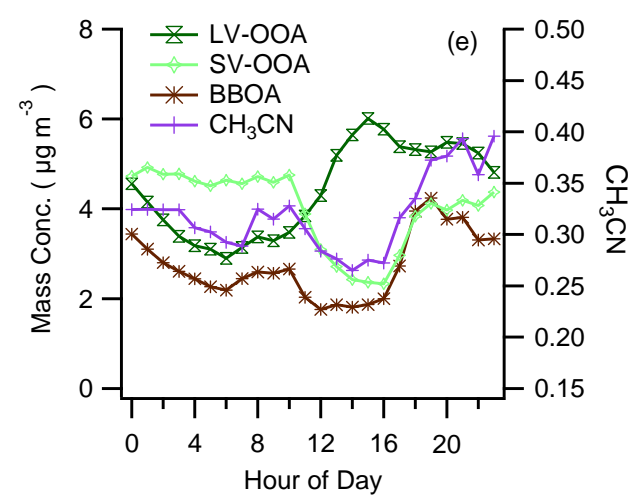

Fig. 6. Time series of (a-c) the OA components and other relevant species; (d) the average OA composition; and (e) the diurnal variations of the OA components and acetonitrile.

2010). OOA time trends typically correlate well with those of inorganic secondary aerosol species, with SV-OOA correlating best with nitrate due to the common semi-volatility and LV-OOA correlating best with sulfate due to the common low volatility (Docherty et al., 2008; Huffman et al., 2009; Jimenez et al., 2009; $\mathrm{Ng}$ et al., 2010). Based on the summarization of $\mathrm{O} / \mathrm{C}$ ratio ranges of OOAs revealed in global AMS measurements, $\mathrm{Ng}$ et al. (2010) have shown a wide range of $\mathrm{O} / \mathrm{C}$ ratio for both $\mathrm{LV}-\mathrm{OOA}(0.73 \pm 0.14)$ and $\mathrm{SV}$ OOA $(0.35 \pm 0.14)$, reflecting the fact that there is a continuum of OOA properties in ambient aerosols. The O/C ratios of the two OOA components identified in this campaign lie within the typical ranges for LV-OOA and SV-OOA, therefore they are referred to as LV-OOA and SV-OOA, respectively, following the existing terminology. In this campaign, the LV-OOA correlated best with sulfate $\left(R^{2}=0.42\right)$ rather than with nitrate $\left(R^{2}=0.13\right)$ while the SV-OOA correlated best with nitrate $\left(R^{2}=0.65\right)$ rather than with sulfate
$\left(R^{2}=0.30\right)$, well consistent with the findings of some previous AMS measurements (Lanz et al., 2007; Docherty et al., 2008; Ulbrich et al., 2009, Huffman et al., 2009). When considering LV-OOA and SV-OOA together, the sum of them showed a quite high correlation with the sum of sulfate and nitrate $\left(R^{2}=0.78\right)$, further confirming their secondary nature of OOA.

It is interesting to note that a hydrocarbon-like (HOA) organic aerosol component, typically distinguished by the ion series of $\mathrm{C}_{n} \mathrm{H}_{2 n+1}^{+}$and $\mathrm{C}_{n} \mathrm{H}_{2 n-1}^{+}$and low $\mathrm{O} / \mathrm{C}$ ratios of $<0.2$ (Jimenez et al., 2009; $\mathrm{Ng}$ et al., 2010), is not identified in this PMF analysis. HOA has been extensively identified in previous AMS measurements and is mainly attributed to primary combustion sources (Zhang et al., 2007; Lanz et al., 2007; Ulbrich et al., 2009). In this PMF analysis, increasing the number of PMF factors only resulted in splitting of the OOA components, as shown in Table S2, and did not yield a new HOA-like component. The fact that a distinct 

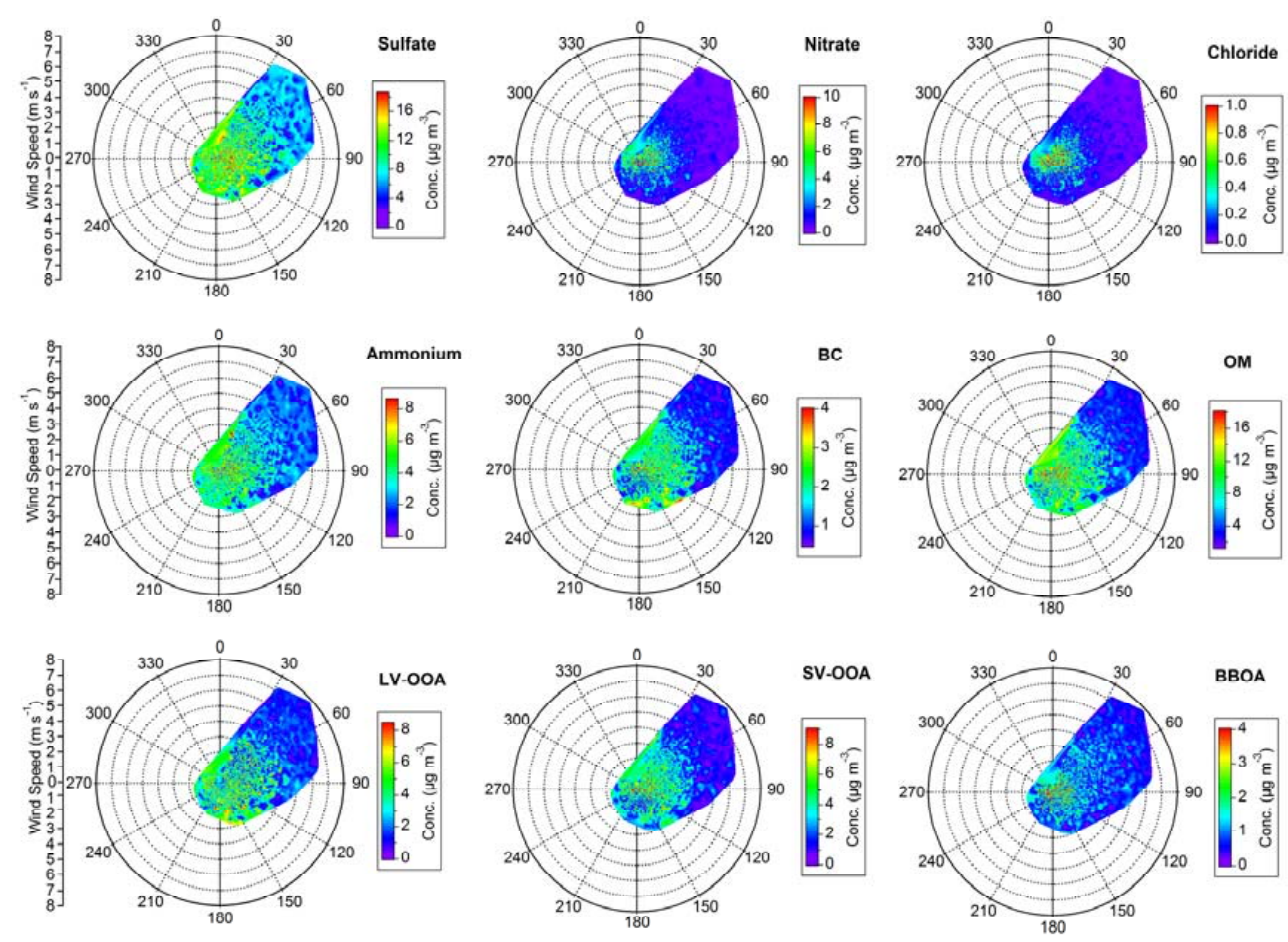

Fig. 7. The variation of $\mathrm{PM}_{1}$ component concentration with wind direction and speed.

HOA component was not extracted for this campaign is a result of Kaiping being a rural site about $120 \mathrm{~km}$ away downwind of the central PRD area. Previous studies have shown a sharp reduction in the HOA contribution to total OA loadings downwind of cities. As illustrated in Zhang et al. (2007), de Gouw et al. (2005), and Jimenez et al. (2009), HOA emitted from cities can be quickly diluted in regional air dominated by OOA and overwhelmed by SOA production. In addition, the HOA from the central PRD area could be oxidized quickly during transport because the atmospheric oxidizing capacity in PRD was demonstrated to be unexpectedly high (Hofzumahaus et al., 2009). Very small contributions of HOA to total OA mass were identified at two similar urban downwind sites, i.e., Taunus, Germany and off New England coast, US, in previous AMS measurements and no HOA was identified in analyses of data from other remote sites (Jimenez et al., 2009).

As shown in Fig. 6e, the average diurnal patterns of the three OA components are also quite different and well consistent with their own origins. The BBOA showed a small morning peak and a large evening peak, which is similar to that of acetonitrile. This type of diurnal pattern could be reasonably attributed to the combined result of the low PBL heights and burning events in the morning and evening. The LV-OOA showed a continuous concentration increase in the daytime, reflecting its large photochemical production in the daytime. As LV-OOA is regarded as aged aerosol, it is inferred to be well mixed in PBL. Therefore, unlike the near- ground emissions, the elevation of PBL in the daytime might not have a strong dilution effect on LV-OOA concentrations. In contrast to the LV-OOA, the diurnal variation of SV-OOA showed large concentration decease in the daytime, similar to that of nitrate, which should be the combined result of its semi-volatility and high PBL heights in the daytime.

\subsection{Influence of meteorology on observed $\mathrm{PM}_{1}$ components}

Wind plays a crucial role in dilution and transport of air pollution, which is especially the case in this study since the Kaiping site is a rural site downwind of the polluted central PRD area. In order to better understand the origins of $\mathrm{PM}_{1}$ at the Kaiping site, it is essential to study the relationship between the components concentrations and wind. Figure 7 plots the distribution of $\mathrm{PM}_{1}$ component concentration versus wind direction and speed, which was mostly northeasterly during the sampling period in PRD. Generally, all the $\mathrm{PM}_{1}$ components showed higher concentrations with lower wind speeds but lower concentrations with higher wind speeds, reflecting the vital role of wind in diluting air pollutants. The contrast, however, was not identical for different $\mathrm{PM}_{1}$ components. Sulfate concentrations were maintained at medium levels even under higher wind speeds of $>4 \mathrm{~m} \mathrm{~s}^{-1}$, indicating that sulfate was a quite regional pollutant that dispersed more uniformly in PRD. For nitrate and chloride, their higher concentrations were constrained with weak 
winds (about $<2 \mathrm{~m} \mathrm{~s}^{-1}$ ), which implies either more local production or more gas-to-particle condensation at lower wind speeds. Considering Kaiping was a rural site with less local emissions, more gas-to-particle condensation of $\mathrm{HNO}_{3}$ due to air pollutant accumulation under calm air conditions seems to be more plausible. Higher BBOA concentrations were mostly associated with wind speeds of $<2 \mathrm{~m} \mathrm{~s}^{-1}$, denoting the dominant role of local burning events. However, there are still some higher BBOA concentrations corresponding to wind speeds of $>2 \mathrm{~m} \mathrm{~s}^{-1}$, suggesting that the regional transport of BBOA also existed. Other $\mathrm{PM}_{1}$ components had higher and relatively uniform concentrations associated with $0-4 \mathrm{~m} \mathrm{~s}^{-1}$ northeasterly wind, without even higher concentrations under weak winds $\left(<2 \mathrm{~m} \mathrm{~s}^{-1}\right)$. This strongly suggests that regional transport from central PRD rather than local emission was the major origins of these $\mathrm{PM}_{1}$ components at the Kaiping site.

\section{Conclusions}

Based on the HR-ToF-AMS measurement at a rural site downwind of the highly-polluted central PRD area during October-November, 2008, the $\mathrm{PM}_{1}$ mass concentrations in 10 min-resolution varied largely between 2.4 and $150 \mu \mathrm{g} \mathrm{m}^{-3}$, with a mean value of $33.1 \mu \mathrm{g} \mathrm{m}^{-3}$. Organics and sulfate were the most abundant species, each accounting for $\sim 1 / 3$ of the total mass, respectively. The high concentration levels of $\mathrm{PM}_{1}$ mass and sulfate are a feature of fine aerosol particles in PRD in comparison with other similar measurements in developed countries. Secondary organic aerosol was found to dominate the $\mathrm{OA}$ at this rural site with the following characteristics: (1) the $\mathrm{O} / \mathrm{C}$ ratio had a clear diurnal pattern that is consistent with that of photochemical activity; (2) PMF analysis indicated that LV-OOA and SV-OOA totally accounted for about three quarters of the total OA; (3) the sum of LV-OOA and SV-OOA showed high correlation with the sum of sulfate and nitrate, strongly confirming their secondary nature. It is interestingly found that BBOA comprised a large OA fraction of about a quarter in this campaign, with its concentration highly elevated after 12 November due to the open field burning of crop residues after harvest in PRD. High N/C ratios were found to be closely associated with biomass burning. Analysis of meteorological influence supported that regional transport from the central PRD area was the major origin of the $\mathrm{PM}_{1}$ components observed at this rural site.

\section{Supplement related to this article is available online at: http://www.atmos-chem-phys.net/11/1865/2011/ acp-11-1865-2011-supplement.pdf.}

Acknowledgements. This work was supported by the " 863 " project (2006AA06A308) from the Ministry of Science and Technology of China, the National Natural Science Funds for Distinguished Young Scholar (21025728), and the National Natural Science Foundation of China (40805049, 20777001)

Edited by: C. K. Chan

\section{References}

Aiken, A. C., DeCarlo, P. F., and Jimenez, J. L.: Elemental analysis of organic species with electron ionization high-resolution mass spectrometry, Anal. Chem., 79, 8350-8358, 2007.

Aiken, A. C., Decarlo, P. F., Kroll, J. H., Worsnop, D. R., Huffman, J. A., Docherty, K. S., Ulbrich, I. M., Mohr, C., Kimmel, J. R., Sueper, D., Sun, Y., Zhang, Q., Trimborn, A., Northway, M., Ziemann, P. J., Canagaratna, M. R., Onasch, T. B., Alfarra, M. R., Prevot, A. S., Dommen, J., Duplissy, J., Metzger, A., Baltensperger, U., and Jimenez, J. L.: O/C and OM/OC ratios of primary, secondary, and ambient organic aerosols with high-resolution time-of-flight aerosol mass spectrometry, Environ. Sci. Technol., 42, 4478-4485, 2008.

Aiken, A. C., Salcedo, D., Cubison, M. J., Huffman, J. A., DeCarlo, P. F., Ulbrich, I. M., Docherty, K. S., Sueper, D., Kimmel, J. R., Worsnop, D. R., Trimborn, A., Northway, M., Stone, E. A., Schauer, J. J., Volkamer, R., Fortner, E., de Foy, B., Wang, J., Laskin, A., Shutthanandan, V., Zheng, J., Zhang, R., Gaffney, J., Marley, N. A., Paredes-Miranda, G., Arnott, W. P., Molina, L. T., Sosa, G., and Jimenez, J. L. : Mexico City aerosol analysis during MILAGRO using high resolution aerosol mass spectrometry at the urban supersite (T0)-Part 1: Fine particle composition and organic source apportionment, Atmos. Chem. Phys., 9, 6633-6653, doi:10.5194/acp-9-6633-2009, 2009.

Alfarra, M. R., Coe, H., Allan, J. D., Bower, K. N., Boudries, H., Canagaratna, M. R., Jimenez, J. L., Jayne, J. T., Garforth, A. A., Li, S. -M., and Worsnop, D. R.: Characterization of urban and rural organic particulate in the lower Fraser valley using two aerodyne aerosol mass spectrometers, Atmos. Environ., 38, 57455758, 2004.

Alfarra, M. R., Prevot, A. S. H., Szidat, S., Sandradewi, J., Weimer, S., Lanz, V. A., Schreiber, D., Mohr, M., and Baltensperger, U.: Identification of the mass spectral signature of organic aerosols from wood burning emissions, Environ. Sci. Technol., 41, 57705777, 2007.

Allan, J. D., Alfarra, M. R., Bower, K. N., Williams, P. I., Gallagher, M. W., Jimenez, J. L., McDonald, A. G., Nemitz, E., Canagaratna, M. R., Jayne, J. T., Coe, H., and Worsnop, D. R.: Quantitative sampling using an Aerodyne AerosolMass Spectrometer. Part 2: Measurements of fine particulate chemical composition in two UK Cities, J. Geophys. Res.-Atmos., 108, 4091, doi:10.1029/2002JD002359, 2003.

Canagaratna, M. R., Jayne, J. T., Jimenez, J. L., Allan, J. D., Alfarra, M. R., Zhang, Q., Onasch, T. B., Drewnick, F., Coe, H., Middlebrook, A., Delia, A., Williams, L. R., Trimborn, A. M., Northway, M. J., DeCarlo, P. F., Kolb, C. E., Davidovits, P., and Worsnop, D. R.: Chemical and microphysical characterization of ambient aerosols with the aerodyne aerosol mass spectrometer, Mass Spectrom. Rev., 26, 185-222, 2007. 
de Gouw, J. A., Warneke, C., Parrish, D. D., Holloway, J. S., Trainer, M., and Fehsenfeld, F. C.: Emission sources and ocean uptake of acetonitrile $\left(\mathrm{CH}_{3} \mathrm{CN}\right)$ in the atmosphere, J. Geophys. Res., 108(D11), 4329, doi:10.1029/2002JD002897, 2003.

de Gouw, J. A., Middlebrook, A. M., Warneke, C., Goldan, P. D., Kuster, W. C., Roberts, J. M., Fehsenfeld, F. C., Worsnop, D. R., Canagaratna, M. R., Pszenny, A. A. P., Keene, W. C., Marchewka, M., Bertman, S. B., and Bates, T. S.: Budget of organic carbon in a polluted atmosphere: results from the New England Air Quality Study in 2002, J. Geophys. Res-Atmos., 110, D16305, doi:16310.11029/12004JD005623, 2005.

DeCarlo, P. F., Kimmel, J. R., Trimborn, A., Northway M. J., Jayne, J. T., Aiken, A. C., Gonin, M., Fuhrer, K., Horvath, T., Docherty, K. S., Worsnop, D. R., and Jimenez, J. L.: Field-deployable, high-resolution time-of-flight aerosol mass spectrometer, Anal. Chem., 78, 8281-8289, 2006.

DeCarlo, P. F., Ulbrich, I. M., Crounse, J., de Foy, B., Dunlea, E. J., Aiken, A. C., Knapp, D., Weinheimer, A. J., Campos, T., Wennberg, P. O., and Jimenez, J. L.: Investigation of the sources and processing of organic aerosol over the Central Mexican Plateau from aircraft measurements during MILAGRO, Atmos. Chem. Phys., 10, 5257-5280, doi:10.5194/acp-10-52572010, 2010.

Docherty, K. S., Stone, E. A., Ulbrich, I. M., DeCarlo, P. F., Snyder, D. C., Schauer, J. J., Peltier, R. E., Weber, R. J., Murphy, S. M., Seinfeld, J. H., Grover, B. D., Eatough, D. J., and Jimenez, J. L.: Apportionment of primary and secondary organic aerosols in Southern California during the 2005 Study of Organic Aerosols in Riverside (SOAR-1), Environ. Sci. Technol., 42, 7655-7662, 2008.

Drewnick, F., Hings, S. S., DeCarlo, P., Jayne, J. T., Gonin, M., Fuhrer, K., Weimer, S., Jimenez, J. L., Demerjian, K. L., Borrmann, S., and Worsnop, D. R.: A new time-of-flight aerosol mass spectrometer (TOF-AMS)-Instrument description and first field deployment, Aerosol. Sci. Tech., 39, 637-658, 2005.

Hagler, G. S. W., Bergin, M. H., Salmon, L. G., Yu, J. Z., Wan, E. C. H., Zheng, M., Zeng, L. M., Kiang, C. S., Zhang, Y. H., Lau, A. K. H., and Schauer, J. J.: Source areas and chemical composition of fine particulate matter in the Pearl River Delta region of China, Atmos. Environ., 40, 3802-3815, 2006.

Han, S., Kondo, Y., Oshima, N., Takegawa, N., Miyazaki, Y., Hu, M., Lin, P., Deng, Z., Zhao, Y., Sugimoto, N., and Wu, Y.: Temporal variations of elemental carbon in Beijing, J. Geophys. Res.Atmos., 114, D23202, doi:10.1029/2009JD012027, 2009.

He, L.-Y., Lin, Y., Huang, X.-F., Guo, S., Xue, L., Su, Q., Hu, M., Luan, S.-J., and Zhang, Y.-H.: Characterization of highresolution aerosol mass spectra of primary organic aerosol emissions from Chinese cooking and biomass burning, Atmos. Chem. Phys., 10, 11535-11543, doi:10.5194/acp-10-11535-2010, 2010.

Heald, C. L., Kroll, J. H., Jimenez, J. L., Docherty, K. S., DeCarlo, P. F., Aiken, A. C., Chen, Q., Martin, S. T., Farmer, D. K., and Artaxo, P.: A simplified description of the evolution of organic aerosol composition in the atmosphere, Geophys. Res. Lett., 37, L08803, doi:10.1029/2010GL042737, 2010.

Hennigan, C. J., Sullivan, A. P., Fountoukis, C. I., Nenes, A., Hecobian, A., Vargas, O., Case Hanks, A. T., Huey, L. G., Lefer, B. L., Russell, A. G., and Weber, R. J.: On the volatility and production mechanisms of newly formed nitrate and water soluble organic aerosol in Mexico City, Atmos. Chem. Phys., 8, 3761-
3768, doi:10.5194/acp-8-3761-2008, 2008.

Hofzumahaus, A., Rohrer, F., Lu K., Bohn, B., Brauers, T., Chang, C. C., Fuchs, H., Holland, F., Kita, K., Kondo, Y., Li, X., Lou, S., Shao, M., Zeng, L., Wahner, A., and Zhang, Y.: Amplified trace gas removal in the troposphere, Science, 324, 1702-1704, 2009.

Huang, X.-F., He, L.-Y., Hu, M., Canagaratna, M. R., Sun, Y., Zhang, Q., Zhu, T., Xue, L., Zeng, L.-W., Liu, X.-G., Zhang, Y.-H., Jayne, J. T., Ng, N. L., and Worsnop, D. R.: Highly time-resolved chemical characterization of atmospheric submicron particles during 2008 Beijing Olympic Games using an Aerodyne High-Resolution Aerosol Mass Spectrometer, Atmos. Chem. Phys., 10, 8933-8945, doi:10.5194/acp-10-8933-2010, 2010.

Huffman, J. A., Docherty, K. S., Aiken, A. C., Cubison, M. J., Ulbrich, I. M., Decarlo, P. F., Sueper, D., Jayne, J. T., Worsnop, D. R., Ziemann, P. J., and Jimenez, J. L.: Chemically resolved aerosol volatility measurements from two megacity field studies, Atmos. Chem. Phys., 9, 7161-7182, doi:10.5194/acp-9-71612009, 2009.

Jayne, J. T., Leard, D. C., Zhang, X. F., Davidovits, P., Smith, K. A., Kolb, C. E., and Worsnop, D. R.: Development of an aerosol mass spectrometer for size and composition analysis of submicron particles, Aerosol. Sci. Tech., 33, 49-70, 2000.

Jimenez, J. L., Jayne, J. T., Shi, Q., Kolb, C. E., Worsnop, D. R., Yourshaw, I., Seinfeld, J. H., Flagan, R. C., Zhang, X.-F., Smith, K. A., Morris, J. W., and Davidovits, P.: Ambient aerosol sampling using the Aerodyne Aerosol Mass Spectrometer, J. Geophys. Res.-Atmos., 108, 8425, doi:10.1029/2001JD001213, 2003.

Jimenez1, J. L., Canagaratna, M. R., Donahue, N. M., Prevot, A. S. H., Zhang, Q., Kroll, J. H., DeCarlo, P. F., Allan, J. D. , Coe, H., Ng, N. L., Aiken, A. C., Docherty, K. S., Ulbrich, I. M., Grieshop, A. P., Robinson, A. L., Duplissy, J., Smith, J. D., Wilson, K. R., Lanz, V. A., Hueglin, C., Sun, Y. L., Tian, J., Laaksonen, A., Raatikainen, T., Rautiainen, J., Vaattovaara, P., Ehn, M., Kulmala, M., Tomlinson, J. M., Collins, D. R., Cubison, M. J., Dunlea, E. J., Huffman, J. A., Onasch, T. B., Alfarra, M. R., Williams, P. I., Bower, K., Kondo, Y., Schneider, J., Drewnick, F., Borrmann, S., Weimer, S., Demerjian, K., Salcedo, D., Cottrell, L., Griffin, R., Takami, A., Miyoshi, T., Hatakeyama, S., Shimono, A., Sun, J. Y., Zhang, Y. M., Dzepina, K., Kimmel, J. R., Sueper, D., Jayne, J. T., Herndon, S. C., Trimborn, A. M., Williams, L. R., Wood, E. C., Middlebrook, A. M., Kolb, C. E., Baltensperger, U., and Worsnop, D. R.: Evolution of organic aerosols in the atmosphere, Science, 326, 1525-1529, 2009.

Kroll, J. H., Smith, J. D., Che, D. L., Kessler, S. H., Worsnop, D. R., and Wilson, K. R.: Measurement of fragmentation and functionalization pathways in the heterogeneous oxidation of oxidized organic aerosol, Phys. Chem. Chem. Phys., 11, 8005-8014, 2009.

Lanz, V. A., Alfarra, M. R., Baltensperger, U., Buchmann, B., Hueglin, C., and Prévôt, A. S. H.: Source apportionment of submicron organic aerosols at an urban site by factor analytical modelling of aerosol mass spectra, Atmos. Chem. Phys., 7, 1503-1522, doi:10.5194/acp-7-1503-2007, 2007.

Laskin, A., Smith, J. S., and Laskin, J.: Molecular characterization of nitrogen-containing organic compounds in biomass burning aerosols using high-resolution mass spectrometry, Environ. Sci. Technol., 43, 3764-3771, 2009.

Lin, P., Hu, M., Deng, Z., Slanina, J., Han, S., Kondo, Y., Takegawa, 
N., Miyazaki, Y., Zhao, Y., and Sugimoto, N.: Seasonal and diurnal variations of organic carbon in $\mathrm{PM}_{2.5}$ in Beijing and the estimation of secondary organic carbon, J. Geophys. Res.-Atmos., 114, D00G11, doi:10.1029/2008JD010902, 2009

Ng, N. L., Canagaratna, M. R., Zhang, Q., Jimenez, J. L., Tian, J., Ulbrich, I. M., Kroll, J. H., Docherty, K. S., Chhabra, P. S., Bahreini, R., Murphy, S. M., Seinfeld, J. H., Hildebrandt, L., Donahue, N. M., Decarlo, P. F., Lanz, V. A., Prévôt, A. S. H., Dinar, E., Rudich, Y., and Worsnop, D. R.: Organic aerosol components observed in Northern Hemispheric datasets from Aerosol Mass Spectrometry, Atmos. Chem. Phys., 10, 46254641, doi:10.5194/acp-10-4625-2010, 2010.

Paatero, P. and Hopke, P. K.: Discarding or downweighting highnoise variables in factor analytic models, Anal. Chim. Acta, 490, 277-289, 2003.

Paatero, P. and Tapper, U.: Positive Matrix Factorization-a Nonnegative Factor Model with Optimal Utilization of Error-Estimates of Data Values, Environmetrics, 5, 111-126, 1994.

Salcedo, D., Onasch, T. B., Dzepina, K., Canagaratna, M. R., Zhang, Q., Huffman, J. A., Decarlo, P. F., Jayne, J. T., Mortimer, P., Worsnop, D. R., Kolb, C. E., Johnson, K. S., Zuberi, B., Marr, L. C., Volkamer, R., Molina, L. T., Molina, M. J., Cardenas, B., Bernabé, R. M., Márquez, C., Gaffney, J. S., Marley, N. A., Laskin, A., Shutthanandan, V., Xie, Y., Brune, W., Lesher, R., Shirley, T., and Jimenez, J. L.: Characterization of ambient aerosols in Mexico City during the MCMA-2003 campaign with Aerosol Mass Spectrometry: results from the CENICA Supersite, Atmos. Chem. Phys., 6, 925-946, doi:10.5194/acp-6-9252006, 2006.

Streets, D., Yu, C., Bergin, M., Wang, X., and Carmichael, G. R.: Modeling study of air pollution due to the manufacture of export goods in China's Pearl River Delta, Environ. Sci. Technol., 40, 2099-2107, 2006.

Ulbrich, I. M., Canagaratna, M. R., Zhang, Q., Worsnop, D. R., and Jimenez, J. L.: Interpretation of organic components from Positive Matrix Factorization of aerosol mass spectrometric data, Atmos. Chem. Phys., 9, 2891-2918, doi:10.5194/acp-8-2891-2009, 2009.
Yuan, B., Liu, Y., Shao, M., Lu, S. -H., and Streets, D. G.: Biomass Burning Contributions to Ambient VOCs Species at a Receptor Site in the Pearl River Delta (PRD), China, Environ. Sci. Technol., 44(12), 4577-4582, 2010.

Zhang, Q., Canagaratna, M. R., Jayne, J. T., Worsnop, D. R., and Jimenez, J. -L.: Time- and size-resolved chemical composition of submicron particles in Pittsburgh: Implications for aerosol sources and processes, J. Geophys. Res.-Atmos., 110, D07S09, doi:10.1029/2004JD004649, 2005a.

Zhang, Q., Worsnop, D. R., Canagaratna, M. R., and Jimenez, J. L.: Hydrocarbon-like and oxygenated organic aerosols in Pittsburgh: insights into sources and processes of organic aerosols, Atmos. Chem. Phys., 5, 3289-3311, doi:10.5194/acp-5-32892005, 2005b.

Zhang, Q., Jimenez, J. L., Canagaratna, M. R., Allan, J. D., Coe, H., Ulbrich, I., Alfarra, M. R., Takami, A., Middlebrook, A. M., Sun, Y. L., Dzepina, K., Dunlea, E., Docherty, K., DeCarlo, P. F., Salcedo, D., Onasch, T., Jayne, J. T., Miyoshi, T., Shimono, A., Hatakeyama, S., Takegawa, N., Kondo, Y., Schneider, J., Drewnick, F., Borrmann, S., Weimer, S., Demerjian, K., Williams, P., Bower, K., Bahreini, R., Cottrell, L., Griffin, R. J., Rautiainen, J., Sun, J. Y., Zhang, Y. M., and Worsnop, D. R.: Ubiquity and dominance of oxygenated species in organic aerosols in anthropogenically-influenced Northern Hemisphere midlatitudes, Geophys. Res. Lett., 34, L13801, doi:10.1029/2007GL029979, 2007.

Zhang, Y. H., Hu M., Zhong L. J., Wiedensohler, A., Liu, S. C., Andreaee, M. O., Wang, W., and Fang, S. J.: Regional Integrated Experiments on Air Quality over Pearl River Delta 2004 (PRIDE-PRD2004): Overview, Atmos. Environ., 42(25), 6157 6173, 2008.

Zheng, J., Zhang, R., Fortner, E. C., Molina, L., Aiken, A. C., Jimenez, J. L., Gäggeler, K., Dommen, J., Dusanter, S., Stevens, P. S., and Tie, X.: Measurements of $\mathrm{HNO}_{3}$ and $\mathrm{N}_{2} \mathrm{O}_{5}$ using ion drift-chemical ionization mass spectrometry during the MILAGRO/MCMA-2006 campaign, Atmos. Chem. Phys., 8, 6823-6838, doi:10.5194/acp-8-6823-2008, 2008. 